\title{
APPLICATION OF THE PRINCIPLE OF EFFICIENCY IN ENSURING SOCIAL AND ECONOMIC SECURITY
}

CShvaiba D., ORCID: 0000-0001-6783-9765, Ph.D.,

Belarusian Trade Union of workers of chemical, mining and oil industries, Belarusian national technical University, Minsk, Belarus, shvabia@tut.by

\section{ПРИМЕНЕНИЕ ПРИНЦИПА РЕЗУЛЬТАТИВНОСТИ ПРИ ОБЕСПЕЧЕНИИ СОЦИАЛЬНО-ЭКОНОМИЧЕСКОЙ БЕЗОПАСНОСТИ}

\author{
СШвайба Д. Н., ORCID: 0000-0001-6783-9765, канд. экон. наук, \\ Белорусский профсоюз работников химической, горной и нефтяной отраслей \\ промышленности, Белорусский начиональный технический университет, \\ 2. Минск, Беларусь, shvabia@tut.by
}

Abstract. The principle of effectiveness is considered important because it determines the importance of the system and the mechanism of ensuring socio-economic security for society. It implies that the objectives of the mechanism (achievement and maintenance of its non-dangerous state and development) are realized with the lowest costs of the company to maintain its functioning on the basis of the necessary complexity of the structure. This means that the system and included in its membership a way to ensure socio-economic security are required to work efficiently from the point of view of rationality of expenses of the company and the significance of the obtained results. The rationality of costs is guided by how they relate to the likely outcomes of ensuring socio-economic security. In combination, they reflect the effectiveness of ensuring social and economic security. But the performance assessment in the presented case is related to the problem of cost and probable outcomes. The problem is that the costs of society have all the chances to be quantified or identified by means of functional dependence, but the bulk of the likely effects (results) obtained as a result of the functioning of the mechanism of ensuring socio-economic security, have a qualitative description. For example, the amount of damage prevented by the system of ensuring social and economic security is quantitatively determined. But outcomes such as "maintaining a competitive advantage" or "maintaining the standard of living" are urged to describe qualitative characteristics that are not easily compared to quantifiable costs.

Аннотациия. Принцип результативности считается важным т. к. определяет значимость системы и механизма обеспечивания социально-экономической безопасности для общества. Он подразумевает, что цели механизма (достижение и поддержание его неопасного состояния и развития) реализуются при наименьших расходах общества на поддержание его функционирования на базе необходимой сложности структуры. Это значит, что система и включаемый в ее состав способ обеспечивания социально-экономической безопасности обязаны работать действенно с точки зрения рациональности расходов общества и значительности получаемых итогов. Рациональность расходов ориентируется тем, как они соотносятся с вероятными итогами обеспечивания социально-экономической безопасности. В комплексе они отображают эффективность обеспечивания социально-экономической безопасности. Но оценка результативности в представленном случае связана с задачей соизмерения расходов и вероятных итогов. Проблема заключается в том, что издержки 
общества имеют все шансы быть оценены количественно или выявлены по средством функциональной зависимости, но основная масса вероятных эффектов (результатов), получаемых вследствие функционирования механизма обеспечивания социальноэкономической безопасности, имеют качественное описание. К примеру, количественно определяется объем предотвращенного системой обеспечивания социально-экономической безопасности вреда. Но такие итоги, как «сохранение конкурентных преимуществ» или же «поддержание достигнутого уровня жизни» настоятельно просят для описания качественных характеристик, которые непросто сопоставить с количественно определяемыми расходами.

Keywords: socio-economic security, government, society, enterprise, employee, threat, security, interests, economics, analysis, system.

Ключевые слова: социально-экономическая защищенность, государство, общество, предприятие, работник, угроза, защищенность, интересы, экономика, анализ, система.

The principle of effectiveness is considered important because it determines the importance of the system and the mechanism of ensuring socio-economic security for society. It implies that the objectives of the mechanism (achievement and maintenance of its non-hazardous state and development) are implemented at the lowest cost to the company to maintain its functioning on the basis of the necessary complexity of the structure. This means that the system and included in its membership a way to ensure socio-economic security are required to work efficiently from the point of view of rationality of expenses of the company and the significance of the obtained results. The rationality of expenditures is guided by how they relate to the likely outcomes of social and economic security. Together, they reflect the effectiveness of social and economic security. But the performance assessment in the present case is related to the task of measuring costs and likely outcomes. The problem is that the costs of society have all the chances to be quantified or identified by means of functional dependence, but the bulk of the likely effects (results) obtained as a result of the functioning of the mechanism of ensuring socio-economic security, have a qualitative description. For example, the amount of damage prevented by the system of ensuring social and economic security is quantified. But such outcomes as "maintaining competitive advantage" or "maintaining the achieved level of life" are urged to describe the quality characteristics that are difficult to compare with quantified costs [1, p. 119]. Based on the above, to assess the effectiveness of socio-economic security, we propose a "cost" approach. The essence of the approach is that the costs of society, due to the tasks of defense of state financial and economic interests and aimed at modifying the system of ensuring socio-economic security in accordance with the evolution of the economy, are considered as target. Taking into account the variety of sources and the complexity of the composition, it makes sense to separate costs according to their purpose - the defense of financial and economic interests ensuring the transformation processes in the structure of the economy (figure 1.).

The costs of society, distributed by hierarchical levels, it is proposed to predetermine based on the array of losses that appear at the macro-and micro-level of the hierarchy of management of economic entities. Management at the macro level is performed through the implementation of functions to ensure socio-economic security of state bodies and special structures. In accordance with this, the losses for their financing are identified in the development of the state budget and are provided as part of the expenditure part. Their total amount is displayed as part of the cost of financing law enforcement, government and management. At the micro level, the provision of socio-economic security is formed mostly by legal services (legal protection of agreements and 
contracts related to the work of enterprises), and financial and economic services in terms of marketing work of economic entities aimed at long-term protection of financial and economic interests. The losses providing financing and functioning of the designated services should be included in the cost of socio-economic security [2; 3].

The significance of these losses for society is not easy to calculate directly, because the work that provides social and economic security, contains all kinds of articles of financing. This is due to the fact that the share of these losses has the ability to be integrated into the cost of production (within the limits permitted by tax legislation), the share is repaid at the expense of profits remaining at the disposal of the economic entity, special funds created at the enterprise, or deductions from the owner of the economic entity. At the same time, the contribution to the joint costs of society to ensure socio-economic security, transactional losses of small and large economic entities is not comparable in volume.

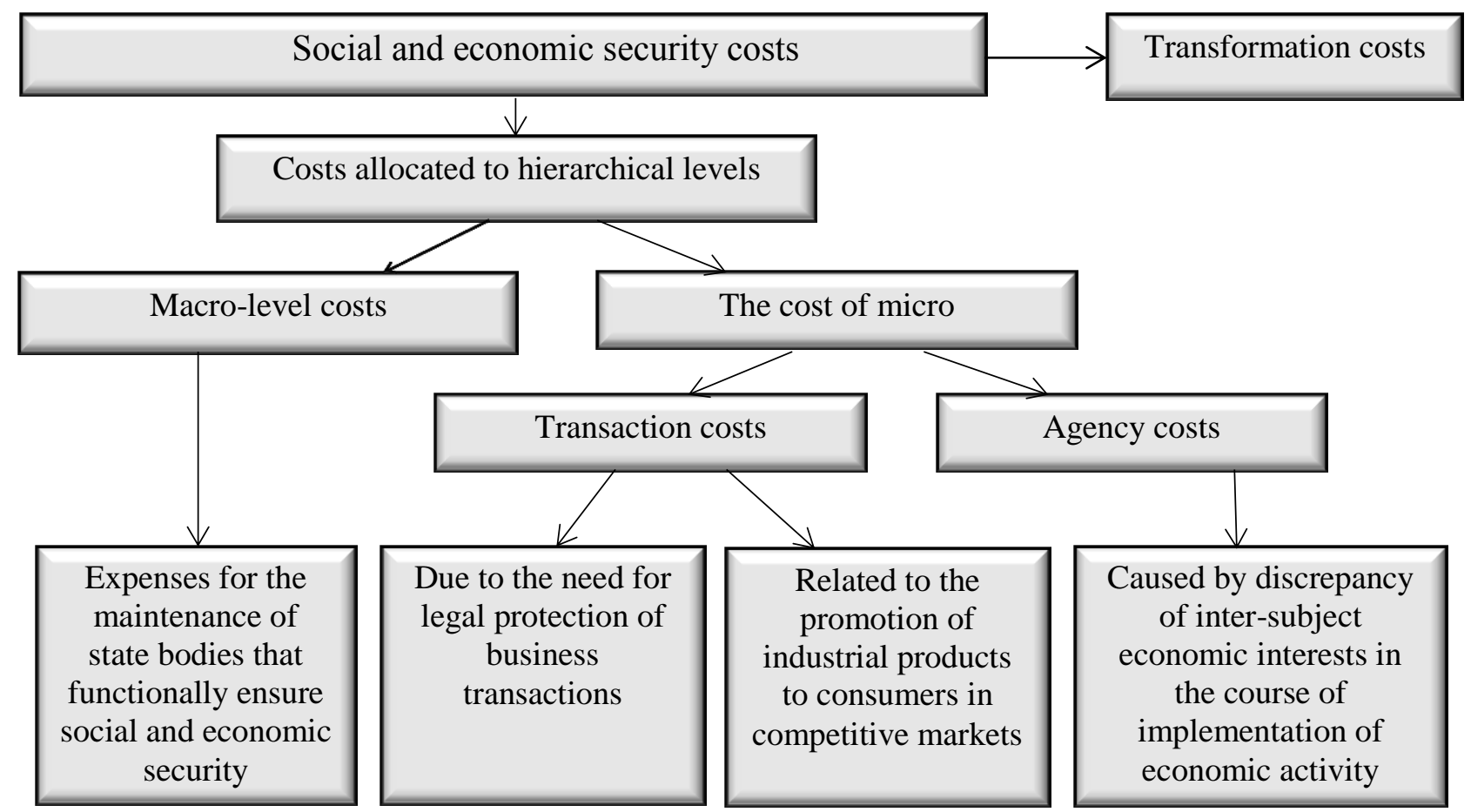

Figure. Total expenses of the company for ensuring social and economic security

Based on this, it makes sense to take into account the transactional losses of large companies, the work of which significantly affects the performance of the economy and its socio-economic security. Their value is proposed to be calculated on the basis of statistical reporting of economic entities on the costs of production and sales. The characteristics of the average share of these losses in the cost of production for the basic stage, calculated as a percentage, and the amount of the cost of production of the current or planned period for all large economic entities have all chances to be applied for the integrated calculation:

$$
\text { Итр = Сикп х Сдт } / 100 \% \text {, }
$$

where: Итр - costs for the maintenance of legal and marketing services of large economic entities for the period;

Сикп - the volume of production costs of large economic entities for the period;

Сдт - the average share of transaction costs in the cost of production of large businesses. 
As demonstrated by the analysis, the functioning of economic entities in a competitive market environment is associated with the probability of manifestation of subjective dangers. Their sources are: the mismatch of inter-subject financial and economic interests, for the resolution of which confrontation methods are preferred, and the use of enterprises of inappropriate ways of managing the changing market conditions.

The manifestation of subjective dangers causes losses due to the incomplete implementation of financial and economic interests of economic entities, and is the value of "lost profits". For example, the lost profit is present if the company is forced to buy material and technical resources in the regional markets at rates higher than the average market. This may be the case with the discrediting activities of competitors aimed at limiting the choice of suppliers for the supply of resources. In addition, the lost profit is likely, if the company on different grounds (reduced competitiveness of products, change in consumer demand, etc.) increase stocks of finished products. The presented situation is justified by the mismatch of financial and economic interests of enterprises-producers and buyers. Generally, costs, characterized as" lost profits", are reflected in the amount of Agency losses. Direct calculation of Agency losses is essentially impossible, because the lost profit is not recorded in the accounts of the economic entity. It is revealed in the process of in-depth financial analysis of the effectiveness of certain economic operations.

Economic operations, upon the implementation of which has the opportunity to "lost profits" are usually justified by the procurement and marketing (commercial) work of the economic entity. Based on this, to determine the Agency losses it is proposed to apply the results of the analysis of the dynamics of the average market tariffs for materials and tariffs purchased by the enterprise of materials. If there is a constant excess of procurement tariffs over the average market, then the "lost profit"is fixed. The lost profit is also revealed in the case when the cost of the finished product of the economic entity is significantly lower than the average market for similar products.

The volume of Agency, as well as transactional losses, makes sense to calculate for large economic entities and profile types of products. For example, to calculate the lost profit in the marketing work of the 1 st economic entity is proposed to apply the formula:

$\Pi$

$$
\begin{aligned}
& \text { УВп= } \Sigma \text { (Цср - Цр) х Опі, } \\
& \mathrm{i}=1
\end{aligned}
$$

where: УВП - lost profit of an economic entity (in monetary terms);

Цср - average market value of a unit of similar products;

Цр - the current cost of selling a unit of production of a particular economic entity;

Oni - sales volume of the i-th type of products (in-kind);

$\Pi$ - the number of main types of products manufactured by an economic entity.

The aggregate amount of Agency losses of the company is calculated by summing up the amount of lost profits calculated for all large economic entities.

Transformational losses arise in connection with the need to modify the conceptual framework and reorientation of the mechanism of ensuring socio-economic security in accordance with the evolution of the economy protected by it. In their composition are connected loss for the targeted monitoring of the ongoing changes and to develop fresh methodological-methodic provisioning, restructuring the system to provide socio-economic security. The source is the data on the allocation of funding for research and implementation of targeted restructuring programs.

It is proposed to use the following information resources to estimate the above costs (Table). 
Table.

DATA SOURCES TO DETERMINE THE COST OF SOCIO-ECONOMIC SECURITY

\begin{tabular}{|l|l|}
\hline \multicolumn{1}{|c|}{ Types of costs } & \multicolumn{1}{c|}{ The sources determine the amount of costs } \\
\hline $\begin{array}{l}\text { Costs for the maintenance of public } \\
\text { administration bodies performing } \\
\text { functions to protect national economic } \\
\text { interests }\end{array}$ & State budget (expenditure part) \\
\hline Transaction costs & $\begin{array}{l}\text { Accounting registers and management documents of business } \\
\text { entities in terms of the costs of legal, marketing and } \\
\text { procurement services }\end{array}$ \\
\hline Agency costs & $\begin{array}{l}\text { Registers of accounting of economic entities in terms of costs } \\
\text { of marketing research, organization of tenders for the purchase } \\
\text { of material and technical resources, storage of stocks of } \\
\text { finished products }\end{array}$ \\
\hline Transformation costs & $\begin{array}{l}\text { Documents about the funding of research and programs for the } \\
\text { restructuring of the economy }\end{array}$ \\
\hline
\end{tabular}

Source: elaboration of author

In General, the losses associated with the formation, operation and modification of the system of socio-economic security, it is proposed to note the term "cost of security".

To assess the extent to which the costs of society to ensure socio-economic security are appropriate, it is proposed to compare their total value with the alternative "price of security". The alternative "price of security" is the value of the harm prevented by the mechanism, which has the possibility to be inflicted on the economy of the state in case of manifestation and realization of more destructive dangers (both subjective and objective). It is proposed to identify the prevented harm on the basis of the assessment of the probable displacement to the worse of the absolute financial and economic characteristics for the moment at which the highest possibility of danger manifestation was recorded. For example, if there was a possibility of risk of failure of supplies of materials, prevented by the method of coordination of financial and economic interests of the subjects of the procurement operation (provision of additional guarantees, acceptable payment terms, etc.), the price of delivery in this case is considered as prevented harm. In the complex, the size of the prevented harm is calculated as a positive financial and economic result of the implementation of economic operations, for which the highest possibility of non-implementation was recorded. The highest possibility is taken at a rate greater than 0.5 .

If we present an economic assessment of the additional costs in the sphere of production caused by the I-th threat, through $У_{г р i}$ and the corresponding probable negative consequences in the associated industries, estimated by means of the amount of economic damage (Уэкj), the alternative "cost of security» (Ца) can be expressed as:

$$
\text { Ца }=\Sigma[\text { Угрі+F(Уэк1, Уэк2,.. Уэкј)], }
$$

where: Угрi — the volume of additional costs in the production sphere caused by the I-th threat;

Уэкј — the volume of economic damage in the $\mathrm{j}$-th industry from the implementation of the Ith threat;

Ца — alternative "security cost". 
Following the logic of the "cost" approach, the condition for effective socio-economic security is:

$$
\text { F(Исод, Итр, Иаг, Иэв })<\Sigma[\text { Угрі+F(Уэк1, Уэк2,.. Уэкј)], }
$$

where:

Исод - expenses for maintenance of special structures to ensure social and economic security;

Итр - expenses for maintenance of legal and marketing services of large economic entities;

Иаг - Agency expenses;

Иэв - transformational costs provoked by evolutionary changes in national production.

The effectiveness of the mechanism of ensuring socio-economic security is proposed to be evaluated on the basis of the aspect of "maximum effectiveness". The proposal is based on the fact that, as a result of their functioning, a more stable functioning of the economy of the state is achieved. In other words, if a system of ensuring social and economic security is formed and operates, it is possible to prevent almost all dangers in time, to "smooth" the negative impact of repeated phases of regression and decline, to implement a number of measures for the defense of competitive advantage, etc. As a result, the aspect of "maximum efficiency" is taken as an evaluation when comparing the actual characteristics of the economy with the parameters determined by the Program of socio-economic formation of the state: the smaller their "divergence", the greater the effectiveness of the system of ensuring socio-economic security. Due to the increase in the effectiveness of the mechanism of ensuring socio-economic security, the design of the resource potential increases in the direction of increasing the share of quality resources, the production resources of a new property are involved in the economic turnover, which contribute to the development of knowledge-intensive sectors of the economy. Apart from that, the sectoral structure of the economy is rationalized in accordance with the global specialization of the state, internal probabilities and the acquired competitive advantage.

The presence of positive changes of a qualitative nature suggests that the effectiveness of the mechanism increases due to the fact that the situation of the protected economic system improves and, as a result, the competitiveness of the state economy in the global financial and economic system is achieved. In this sense, the effectiveness of the mechanism of ensuring socio-economic security is considered as a condition for the implementation of the modern functioning of the state and maintaining its status as a full member of the globalizing economy.

Thus, the proposed framework and model for the formation of an organizational mechanism to ensure socio-economic security are designed to guide the protective perimeter of the economy of the Republic of Belarus in the direction of global evolution.

\section{References:}

1. Radosteva, M. V. (2016). The constitutional regulation of wages in Russia: economic and legal aspects. Journal of Economy and entrepreneurship, (9). 117-122.

2. Shvaiba, D. (2018). Structural stability and socio-economic security of the hierarchical system. Bulletin of Science and Practice, 4(6), 233-239.

3. Shvaiba, D. (2018). Socio-economic security of the hierarchical system. Bulletin of Science and Practice, 4(6), 248-254. 


\section{Список литературы:}

1. Радостева М. Конституционное регулирование заработной платы в Российской Федерации: экономико-правовой аспект // Экономика и предпринимательство. 2016. № 9. С. $117-122$.

2. Shvaiba D. Structural stability and socio-economic security of the hierarchical system // Бюллетень науки и практики. 2018. Т. 4. №6. С. 233-239.

3. Shvaiba D. Socio-economic security of the hierarchical system // Бюллетень науки и практики. 2018. Т. 4. №6. С. 248-254.

Работа поступила

в редакциюю 17.01.2019 г.
Принята к публикациии 21.01.2019 2.

Cite as (APA):

Shvaiba, D. (2019). Application of the principle of efficiency in ensuring social and economic security. Bulletin of Science and Practice, 5(2), 228-234. https://doi.org/10.33619/2414-2948/39/30 (in Russian).

Ссылка для ичитирования:

Shvaiba D. Application of the principle of efficiency in ensuring social and economic security // Бюллетень науки и практики. 2019. Т. 5. №2. С. 228-234. https://doi.org/10.33619/2414$2948 / 39 / 30$ 